\title{
Bionomics of patterned herbicide application for wildlife habitat enhancement
}

\author{
C.J. SCIFRES, W.T. HAMILTON, B.H. KOERTH, R.C. FLINN, AND R.A. CRANE
}

\section{Abstract}

Outcomes of net-present value analyses were projected for patterned applications of herbicide sprays and pellets to mixed brush in south Texas. Picloram + 2,4,5-T (1:1) were applied but 1987 costs of triclopyr + picloram sprays, currently registered and considered the biological equivalent treatment, were used for analyses. Projected internal rates of return (IRR) ranged from 7.3 to $8.5 \%$ when 60 to $65 \%$ of the landscape was sprayed in a variable-rate pattern (VRP) at $0,0.6$, and $1.1 \mathrm{~kg} / \mathrm{ha}$; sprayed in strips with the higher dosage alternating with untreated strips; or completely sprayed with $1.1 \mathrm{~kg} / \mathrm{ha}$. Investment capital requirements were reduced when the VRP or strips were used by $49 \%$ and $35 \%$, respectively, compared to complete treatment of the landscape with herbicide sprays. Treatment of $80 \%$ of landscapes at 2 locations with tebuthiuron in VRPs generated IRRs roughly equivalent to those from $2.2 \mathrm{~kg} \mathrm{ai} / \mathrm{ha}$ of tebuthiuron pellets applied in strips. Complete treatment of management units with $2.2 \mathrm{~kg} / \mathrm{ha}$ of the pellets generated more additional beef and higher IRRs than did treatment with either pattern, but required from $50 \%$ to $75 \%$ greater investments of capital. Economic response also differed among sites of differing forage production capabilities and between otherwise similar sites because of variation in botanical composition of the brush stands. For example, IRRs at the locations, respectively, were 6.3 and $1.3 \%$ when $2.2 \mathrm{~kg} / \mathrm{ha}$ of tebuthiuron were applied to sites with deep soils (drainages), 3.1 and $<0 \%$ following treatment of uplands, and were negative following application to shallow ridges. Sites with a greater proportion of the woody cover contributed by tebuthiuron-susceptible species such as whitebrush yielded greater IRRs from the investment than did sites with heavy cover of honey mesquite (tebuthiuron tolerant).

Key Words: range economics, integrated brush management systems

The increased value of trespass rights for hunting during the past decade has greatly enhanced potential income from rangelands, especially in south Texas. Although woody plant cover suppresses forage production for livestock consumption, it is necessary for quality habitat for income producing game such as white-tailed deer (Odocoileus virginianus), bobwhite quail (Colinus virginianus), collared peccary (Tayassu tajacu), mourning dove (Zenaida macroura), and wild turkey (Meleagris gallopavo).

The potential conflict between range livestock production and game management objectives provides the impetus for investigating the feasibility of partial treatment of rangeland designated for multiple-use management. The response of game animals to application of herbicides to $80 \%$ of the landscape in strips alternating with untreated strips (Beasom and Scifres 1977, Tanner et al. 1978)

\footnotetext{
At the time of this research authors were Thomas M. O'Connor professor, senior lecturer and research associates, Department of Range Science, Texas A\&M University, College Station 77843. Scifres presently is professor and head, Agronomy Department, Oklahoma State University, Stillwater 74078. Koerth's address is La Copita Research Area, Rt. 1, Box 203, Alice, Texas 78332. Published with approval of the Director, Texas Agr. Exp. Sta.

Cooperation of Ed.Harte and Juan Martinez, Cerrito Prieto Ranch, Encinal and R.E. Whitson, Frost National Bank, San Antonio, and use of their land for this research are appreciated. The authors also appreciate the aid of Julia Scifres in manuscript preparation, David Embry for furnishing soils information, and J.R. Conner for consultation relative to economic analyses.

Manuscript accepted 29 February 1988.
}

and the associated economic implications (Whitson et al. 1977) have been documented. Based on the positive attributes of herbicide application in strips, an alternative approach, referred to generically as "variable-rate patterning," was recently described (Scifres and Koerth 1986). Variable-rate patterns (VRPs) are installed by applying herbicide in strips alternating with untreated strips in 2 directions, the second set of strips at right angles to the first, resulting in an array of blocks treated with different herbicide rates. The interspersion of shrub-dominated blocks and shrubherbaceous patches (lower herbicide rate) with herb-dominated blocks where shrubs were controlled by the higher herbicide rate creates a mosaic of vegetation (Scifres and Koerth 1986). Thus, advantages of variable rate patterns, compared to treatment in strips or undisturbed landscapes with heavy brush cover, include increased edge effect and botanical diversity of habitat.

The objective of this research was to evaluate the economic merits of VRPs, strip patterns, and complete treatment of brushdominated range on the South Texas Plains relative to projected changes in livestock production.

\section{Materials and Methods}

\section{Patterned Application of Aerial Sprays}

Picloram (4-amino-3,5,6-trichloro-2-pyridinecarboxylic acid) + 2,4,5-T [(2,4,5-trichlorophenoxy)acetic acid] (1:1) sprays were aerially applied to 2 pastures within a 4-pasture, 1-herd grazing system. Three-rate $(0,0.6$, and $1.1 \mathrm{~kg} / \mathrm{ha}) \mathrm{VRPs}$ were applied to a 198-ha pasture and to a 238-ha pasture on 11 and 20 May 1982, respectively. The study site was located approximately $52 \mathrm{~km}$ north and $13 \mathrm{~km}$ west of Laredo, Texas, where long-term average annual rainfall is $54 \mathrm{~cm}$. The study area is characterized by deep, welldrained, loamy uplands with soils of the Duval series (Aridic Halplustalfs). Duval soils are included in a Sandy Loam range site, and slopes range from 0 to $3 \%$. The mixed-brush cover was dominated by honey mesquite (Prosopis glandulosa) in association with varying proportions of blackbrush acacia (Acacia rigidula), spiny hackberry (Celtis pallida), lotebush (Zizyphus obtusifolia), Texas persimmon (Diospyros texana), desert yaupon (Schaefferia cunefolia), pricklypear (Opuntia spp.), whitebrush (Aloysia lycioides), guajillo (Acacia berlandieri) and 8 or more other shrubs and subshrubs.

The pattern was developed in the 198-ha pasture by applying the herbicide in alternating treated and untreated $147-\mathrm{m}$-wide strips in a north-south direction and alternating 147 -m-treated and $219-\mathrm{m}$ untreated strips in an east-west direction. The pattern was installed in the 238-ha pasture by alternating treated and untreated strips $120 \mathrm{~m}$ wide in a north-south direction and alternating 128 -m-widetreated and 193-m-wide-untreated strips in an east-west direction. A drainage (Ramadero range site) that traversed both pastures was not treated. The herbicide was applied in approximately $13-\mathrm{m}$ wide swaths in $48 \mathrm{~L} /$ ha of an oil:water (1:3) emulsion.

The patterning from the herbicide application and the untreated Ramadero site resulted in approximately $35 \%$ of the 198-ha pasture receiving no herbicide, $45 \%$ treated with $0.6 \mathrm{~kg} / \mathrm{ha}$, and $20 \%$ receiving $1.1 \mathrm{~kg} / \mathrm{ha}$. Approximately $40 \%$ of the 238 -ha pasture was untreated, $40 \%$ received $0.6 \mathrm{~kg} / \mathrm{ha}$ of herbicide, and $20 \%$ was treated with $1.1 \mathrm{~kg} / \mathrm{ha}$. 
Three blocks receiving each treatment $(0,0.6,1.1 \mathrm{~kg} / \mathrm{ha})$ were randomly selected from each of the pastures (total 18 blocks). Initial standing crop was estimated in early May 1982 by clipping herbs to a $2.5-\mathrm{cm}$ stubble height in fifteen $0.25-\mathrm{m}^{2}$ frames equidistantly spaced along the diagonal of each block. Samples were separated into grasses and forbs, oven-dried $\left(60^{\circ} \mathrm{C}\right.$ for 48 hours), and weighed. Fifteen exclosures, $1.2 \mathrm{~m}$ diam and $2 \mathrm{~m}$ tall, were spaced as the sampling points above in August 1982 (270 exclosures). Standing crop was estimated within and $1 \mathrm{~m}$ outside the exclosures by harvesting 59 to a $2.5-\mathrm{cm}$ stubble height in late winter (February), spring (April-May), summer (June-July), and autumn (October-November) each year from 1983 through summer 1987. Following each sampling, exclosures were relocated, based on random selection of a cardinal direction, $3 \mathrm{~m}$ from the previous location.

Initial woody cover and composition was characterized using the point-centered-quarter technique (Cottam and Curtis 1956) at 25 , equidistantly spaced points along the diagonal of each block. Species and canopy diameter of the nearest individual in each quadrant were recorded. Woody plant response to the herbicide was evaluated in August 1982, 1983, 1985, and 1987 by walking a belt transect, approximately $4 \mathrm{~m}$ wide and down the center of each block used for monitoring herbaceous vegetation, and in 3 to 5 additional blocks treated with each herbicide in each pasture. Percentage canopy reduction was estimated for each individual of each species within the belts. Apparent mortality was based on proportion of plants completely defoliated without signs of basal sprouting.

\section{Patterned Applications of Pellets}

Two sites, the first about $19 \mathrm{~km}$ north and $9 \mathrm{~km}$ east of Pearsall, Texas, and a second about $8 \mathrm{~km}$ east of the VRP established with aerial sprays near Laredo, were selected for study of tebuthiuron ( $N$-[5-(1,1-dimethylethyl)-1,3,4-thiadiazol-2-yl]- $N, N^{N}$-dimethylurea) on VRPs. Landscapes were typified by mixed-brush uplands; ridges with shallow, gravelly soils dominated by blackbrush acacia and guajillo; and drainages dominated by varying proportions of honey mesquite and whitebrush. Average annual precipitation is $62 \mathrm{~cm}$ for the Pearsall location.

The deep upland soils at the Laredo site are clay loams of the Moglia series (Ustollic Calciorthids). Moglia soils are included in a Clay Loam range site and slopes range from 1 to $5 \%$. Soils on ridges are fine sandy loams of the Copita series (Ustollic Calciorthids). Copita soils at the site are on summits and vegetation is typical of the shallow sites within the area. Copita soils are included in a Gray Sandy Loam range site. Soils in the drainage are sandy clay loams of the Tela series (Typic Argiustolls). They are deep, nearly level soils in shallow, narrow valleys along small drainageways, are frequently flooded, and are included in a Ramadero range site.

Deep upland soils at the Pearsall site are predominantly sandy clay loams typified by the Zavco series (Aridic Argiustolls). Zavco soils are included in a Clay Loam range site, and slopes of these soils on the study area range from 1 to $3 \%$. Soils on the ridges at the Pearsall site are saline clay loams of the Schattel series (Aridic Ustocherpts). The Schattel series is included in a Saline Clay range site and slopes ranged from 1 to $8 \%$. Soils in the drainage are sandy clay loams of the Amphion series (Pachic Paleustolls). Amphion soils at the study site occur in long, narrow valleys with slopes less than $1 \%$, and are included in a Clay Loam range site.

Tebuthiuron pellets were applied with fixed-wing aircraft in 137-m-wide strips alternating with untreated strips of the same width at both study areas. The 72.2-ha area near Pearsall was treated on 13 May 1982. Strips were treated north-south and then east-west with $1.1 \mathrm{~kg}$ active ingredient (ai)/ ha resulting in 1.9-ha blocks treated with $0,1.1$, or $2.2 \mathrm{~kg} / \mathrm{ha}$ (Fig. 1). Distribution of the shrub stands resulted in blocks of blackbrush acacia-guajillodominated ridge being treated only with 0 and $1.1 \mathrm{~kg} / \mathrm{ha}$, but each of the 3 tebuthiuron dosages occurred on the mesquite-whitebrush

\begin{tabular}{|c|c|c|c|c|c|c|c|}
\hline \multirow[b]{2}{*}{$1.1 \mathrm{~kg} / \mathrm{ha}=$} & \multicolumn{2}{|c|}{$\begin{array}{c}1.1 \\
\mathrm{~kg} / \mathrm{ha}\end{array}$} & \multicolumn{2}{|c|}{$\begin{array}{c}1.1 \\
\mathrm{~kg} / \mathrm{ha}\end{array}$} & \multicolumn{2}{|c|}{$\begin{array}{c}1.1 \\
\mathrm{~kg} / \mathrm{ha}\end{array}$} & $\mathrm{kg} / \mathrm{ha}$ \\
\hline & 2.2 & 1.1 & 2.2 & 1.1 & 2.2 & 1.1 & 2.2 \\
\hline & 1.1 & 0 & 1.1 & 0 & 1.1 & 0 & 1.1 \\
\hline $1.1 \mathrm{~kg} / \mathrm{ha}$ & 2.2 & 1.1 & 2.2 & 1.1 & 2.2 & 1.1 & 2.2 \\
\hline & 1.1 & 0 & 1.1 & 0 & 1.1 & 0 & 1.1 \\
\hline $1.1 \mathrm{~kg} / \mathrm{h}$ & 2.2 & 1.1 & 2.2 & 1.1 & 2.2 & 1.1 & 2.2 \\
\hline & 1.1 & 0 & 1.1 & 0 & 1.1 & 0 & 1.1 \\
\hline $1.1 \mathrm{~kg} /$ & 2.2 & 1.1 & 2.2 & 1.1 & 2.2 & 1.1 & 2.2 \\
\hline
\end{tabular}

Pearsall

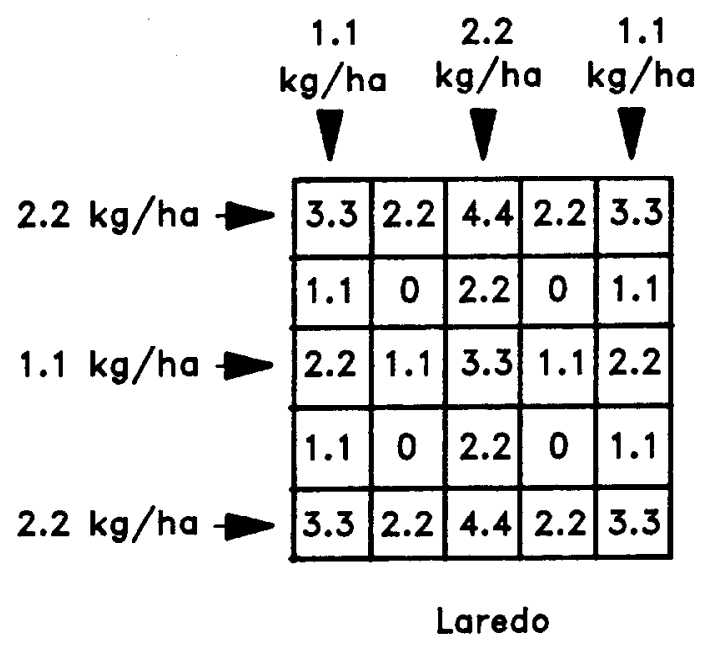

Fig. 1. Distribution of tebuthiuron rates where variable-rate patterns were applied to mixed-brush dominated landscapes in 1982 and 1983, near Pearsall and Laredo, Texas, respectively. Each square is 137 - by $137 \mathrm{~m}$ (ca. $1.9 \mathrm{ha}$ ). Patterns are generalized in that topographical features and dimensions of actual pastures are not considered (i.e. only 72.2 of the possible 91.9 ha were included in the design near Pearsall).

drainage and mesquite-mixed brush uplands.

Tebuthiuron was applied to the 47-ha area near Laredo on 29 March 1983. Strips were treated north-south in the order, 1.1, 0, $2.2,0$, and $1.1 \mathrm{~kg} / \mathrm{ha}$; and then east-west in the order, $2.2,0,1.1,0$, and $2.2 \mathrm{~kg} / \mathrm{ha}$ (Fig. 1). The resultant pattern included 4 untreated blocks, 6 blocks at $1.1 \mathrm{~kg} / \mathrm{ha}, 8$ blocks at $2.2 \mathrm{~kg} / \mathrm{ha}, 5$ blocks at 3.3 $\mathrm{kg} / \mathrm{ha}$, and 2 blocks at $4.4 \mathrm{~kg} / \mathrm{ha}$. The patterns resulted in treatment of $80 \%$ of the study areas at both locations where tebuthiuron was evaluated.

Immediately following herbicide application, the point-center quarter method (Cottam and Curtis 1956) was used to characterize woody vegetation as described for the aerially sprayed VRP. Two blocks of each site receiving each rate were selected for posttreatment monitoring near Pearsall; all blocks were evaluated at the area near Laredo. Percentage canopy reduction of woody species occurring in a 6-m-wide belt down the center of each plot was recorded on 24 to 25 August 1983; 24 to 27 July 1984; 21 to 23 
August 1985 near Pearsall. The area near Laredo was evaluated on 14 to 16 September $1983 ; 26$ to 28 June 1985 ; and 23 to 25 October 1985. Based on these evaluations, the species were placed into arbitrary categories of susceptibility to tebuthiuron as follows: highly tolerant (no noticeable reaction to tebuthiuron); tolerant (no noticeable reaction to $2.2 \mathrm{~kg}$ / ha of tebuthiuron, less than $25 \%$ canopy reduction from $3.3 \mathrm{~kg} / \mathrm{ha}$ ); susceptible (at least $80 \%$ of the individuals killed by $2.2 \mathrm{~kg} / \mathrm{ha}$ ); and highly susceptible (at least $80 \%$ of the individuals killed by $1.1 \mathrm{~kg} / \mathrm{ha}$ of tebuthiuron). Species groupings in each category agreed with previous assessments (Scifres et al. 1979).

Ten grazing exclosures, $1.2 \mathrm{~m}$ diam and $2 \mathrm{~m}$ tall, were placed along the diagonal in 2 blocks each selected for each site and tebuthiuron rate. On the dates of woody plant evaluations, standing herbage was harvested to a $2.5-\mathrm{cm}$ stubble height from $0.25-\mathrm{m}^{2}$ areas from within each exclosure and at $1 \mathrm{~m}$ from the exclosure. The exclosures were then relocated as described for the experiment with aerial sprays. In addition, the standing herbage was estimated for every block in 1983 and in August 1986 using double-sampling. Standing crop was visually estimated in 100 , equally spaced, 0.25 $\mathrm{m}^{2}$ plots across the center of each block. At every fifth sample, the standing crop was harvested. Visual estimates were regressed against oven-dry $\left(60^{\circ} \mathrm{C}, 72 \mathrm{hr}\right)$ weights of the clipped samples.

\section{Economic Analyses}

Livestock production changes attributable to brush control were estimated from forage yields for each block and location (Whitson et al. 1979). The conversion to livestock carrying capacity assumes a daily forage requirement of $12 \mathrm{~kg} / \mathrm{AU}$ and adjusts for forage losses such as to insects, trampling, and weathering. The technique projects annual carrying capacity through the planning profile and has been used in previous analyses (Garoian et al. 1984; Scifres 1987; Whitson and Scifres 1980, 1981; Whitson et al. 1977). Stocking rates used by cooperating producers on untreated rangeland immediately adjacent to the experiments with tebuthiuron were comparable to estimates for untreated plots. Estimated carrying capacities for the aerially sprayed VRP were confirmed by comparison to actual values from producer records for the 2 untreated pastures. Annual livestock carrying capacities on a pasture-wide basis were calculated using a weighted value based on the proportion of the area contributed by each site-herbicide rate combination through midsummer 1987. Projections for the remainder of the 20-year planning profiles were simulated from curves developed from an 11-year experiment with tebuthiuron in the general area (Scifres 1987), and from past experience with applications of 2,4,5-T + picloram in the region (Whitson and Scifres 1980). Changes in calf weaning weights and calf crop were estimated using published procedures (Whitson et al. 1979, Whitson and Scifres 1980).

Using the same procedures, livestock carrying capacities were calculated as if $80 \%$ of each area treated with tebuthiuron had been treated in alternating strips with $2.2 \mathrm{~kg} / \mathrm{ha}$ of the herbicide. Carrying capacities were also estimated as if $65 \%$ of the pastures aerially sprayed had been treated in alternating strips with $1.1 \mathrm{~kg} / \mathrm{ha}$ of 2,4,5-T + picloram. The strips were assumed to be composed of the same proportion of sites as in the respective VRP. Carrying capacity for the Laredo site treated with tebuthiuron was then calculated as if a 3-rate VRP had been installed as on the Pearsall study area. Carrying capacities were then calculated for each respective study area as if the entire pastures had been treated with $2.2 \mathrm{~kg} / \mathrm{ha}$ of tebuthiuron or $1.1 \mathrm{~kg} / \mathrm{ha}$ of 2,4,5-T + picloram. Finally, the estimated relative contribution of each of the major sites within each pasture treated with tebuthiuron was calculated by projecting carrying capacities following application of $2.2 \mathrm{~kg} / \mathrm{ha}$ of the herbicide as if the site accounted for the entire area of pasture.

Economic evaluations of the systems were based on multiyear partial budgeting techniques (Garoian et al. 1984; Whitson and Scifres 1980, 1981). Annual costs and returns in constant 1987 dollars were calculated for each treatment as if applied to a 405-ha pasture. Annual costs included brush treatment(s), livestock investment costs, and additional variable costs. Returns were calculated as additional beef sold, reduced management costs, and livestock disinvestment. Assumptions underlying the analyses included:

1) Cost of tebuthiuron pellets was $\$ 55.13 / \mathrm{kg}$ ai and aerial application cost $\$ 21.00 /$ ha; costs for aerial spraying were $\$ 39.54 /$ ha for $0.6 \mathrm{~kg} / \mathrm{ha}$ and $\$ 65.48 / \mathrm{ha}$ for $1.1 \mathrm{~kg} / \mathrm{ha}$. Aerial spraying costs were based on 1987 prices for applying the respective rates of a 1:1 mixture of triclopyr ([3,5,6-trichloro-2-pyridinyl)oxy]acetic acid) and picloram, currently registered and considered equivalent in efficacy to 2,4,5-T + picloram.

2) Purchase and selling prices/animal were $\$ 650$ for cows and $\$ 1,250$ for breeding males ( 1 breeding male included for each 19 cows).

3) Annual variable cost was $\$ 80.00 / \mathrm{AU}$.

4) Selling price of calves over the planning horizon was $\$ 1.43 / \mathrm{kg}$.

5) Interest charge on the investment capital was $8 \%$.

6) There was no loss of hunting revenues if landscapes were completely treated with herbicide (i.e., contrasts of returns on investment between complete treatment and patterned applications are conservative).

Economic comparisons are based on internal rates of return (IRRs), net-present values (NPVs), timing and magnitude of cash flows, and cumulative additional beef attributable to treatment over the planning horizon for the selected patterns. Determination of NPVs requires that annual costs and returns be discounted to the present (Hopkin et al. 1973). The discount rate reflects time preference for money and risk under the assumption of constant price levels. A $10 \%$ discount rate was arbitrarily selected for comparing alternatives. The discount rate maintains that response to treatment must generate a $10 \%$ rate of return on investment before the NPV will be positive (i.e., when NPV $=0$, all costs have been paid and $10 \%$ has been generated on the investment).

IRRs and NPVs were also calculated for each site within each study area treated with tebuthiuron, except for the ridge site near Laredo, with treatment costs of \$24.71, \$49.42, \$74.13, \$98,84, $\$ 123.55$ and $\$ 144.50 / \mathrm{ha}$. The $\log$ of the resultant IRR ( $Y$ ) and the corresponding treatment cost $(X)$ were used in model I regression to predict the treatment cost required to generate a $10 \%$ IR R on the investment holding all other variables (livestock investment costs, livestock price, variable costs etc.) constant.

\section{Results and Discussion}

Projected IRRs varied from $7.3 \%$ (complete spray) to $8.5 \%$ (alternating strips) for application of aerial sprays to mixed brush near Laredo (Table 1). This contrast is considered conservative since no reduction in hunting revenues was estimated for the scenario involving complete treatment of the landscapes. It is likely

\section{Table 1. Internal rates of return (IRR), accumulated net cash now, net- present value (NPV) of treatment, and costs for treatment of $65 \%$ of hypothetical 405-ha pactures with aerial sprnys of picloram + 2,4,5-T (1:1) in a 3-rate VRP or alternating stripu compared to complete treat- ment of mixed-brubb-dominated landscapes near Laredo, Texas ualng a $10 \%$ discount rate.}

\begin{tabular}{lccc}
\hline \hline & \multicolumn{3}{c}{ Pattern } \\
\cline { 2 - 4 } Variable & VRP & Strips & $\begin{array}{c}\text { Complete } \\
\text { spray }\end{array}$ \\
\hline IRR (\%) & 8.1 & 8.5 & 7.3 \\
Accumulated net cash flow & & & \\
Year positive & 7 & 7 & 7 \\
At year 20 (\$) & 4,850 & 8,259 & 8,499 \\
Treatment costs (S/ha) & 33.61 & 42.58 & 65.45 \\
NPV (S) & $-1,785$ & -1.943 & $-5,453$ \\
\hline
\end{tabular}


that white-tailed deer populations will be reduced for several years on sites completely sprayed (Beasom and Scifres 1977). Treatment costs $(\$ /$ ha), based on area of the entire management unit, were reduced by $49 \%$ with the VRP and by $35 \%$ for alternating strips compared to cost for complete spraying. Accumulated (nondiscounted) net cash flow was first positive in year 7, regardless of alternative pattern. However, accumulated net cash flow from livestock production was reduced by $45 \%$ when the VRP was selected over complete spraying. In contrast, accumulated net cash flow at year 20 was similar between complete spraying and treatment of $80 \%$ of the landscape in alternating strips.

Projected IRRs from application of tebuthiuron varied little among pattern of treatment near Pearsall with returns from the 3-rate pattern intermediate between complete treatment and installation of alternating strips (Table 2). IRRs varied from 1.8 to $3.9 \%$,

Table 2. Treatment conts for selected application patterns with tebuthluron pellets, projected increases in sales weight of beef accumulated over the 20-year planning horizon, net-present values (NPV) and internal rates of retum (IRR) on the inveatments following treatment of mixed bruch at 2 locations in south Texas.

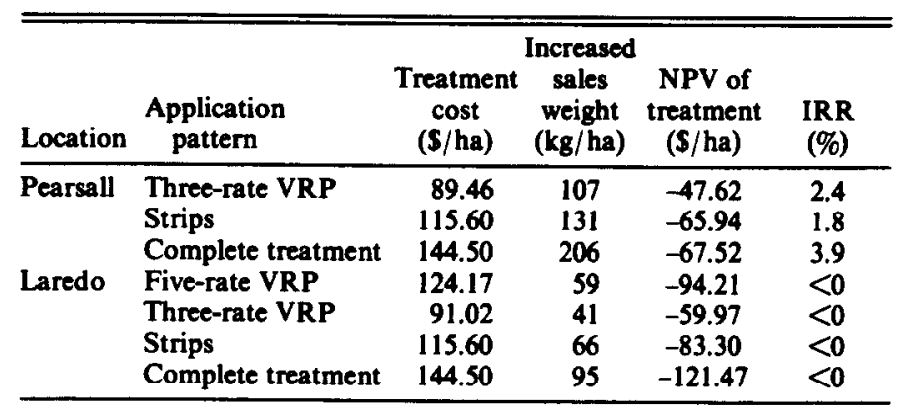

comparable to the $2.3 \%$ rate of return estimated from an 11 -year study of the economic performance of $2.2 \mathrm{~kg} / \mathrm{ha}$ of tebuthiuron in the same physiographic region (Scifres 1987). Based on 1987 herbicide and contract application prices, the 3-rate VRP cost $48 \%$ less than complete treatment and $23 \%$ less than application of 2.2 $\mathrm{kg} /$ ha in alternating strips.

Projected IRRs were negative, regardless of treatment pattern, after application of tebuthiuron near Laredo (Table 2). Increased sales weights of beef projected for the pasture near Laredo were roughly half the response projected for the same patterns applied to the area near Pearsall. The 5-rate VRP treatment cost was $7.4 \%$ more and the 3-rate VRP cost was $21 \%$ less than treating the same land area in alternating strips with $2.2 \mathrm{~kg} / \mathrm{ha}$ of tebuthiuron.

The difference in economic response of the study areas following tebuthiuron application (Table 2) was attributed largely to differences in botanical composition of the mixed-brush stands. With the exception of upland sites, range sites on the area near Laredo were characterized by greater canopy cover of tebuthiurontolerant species (Table 3), accounting for much of the difference in

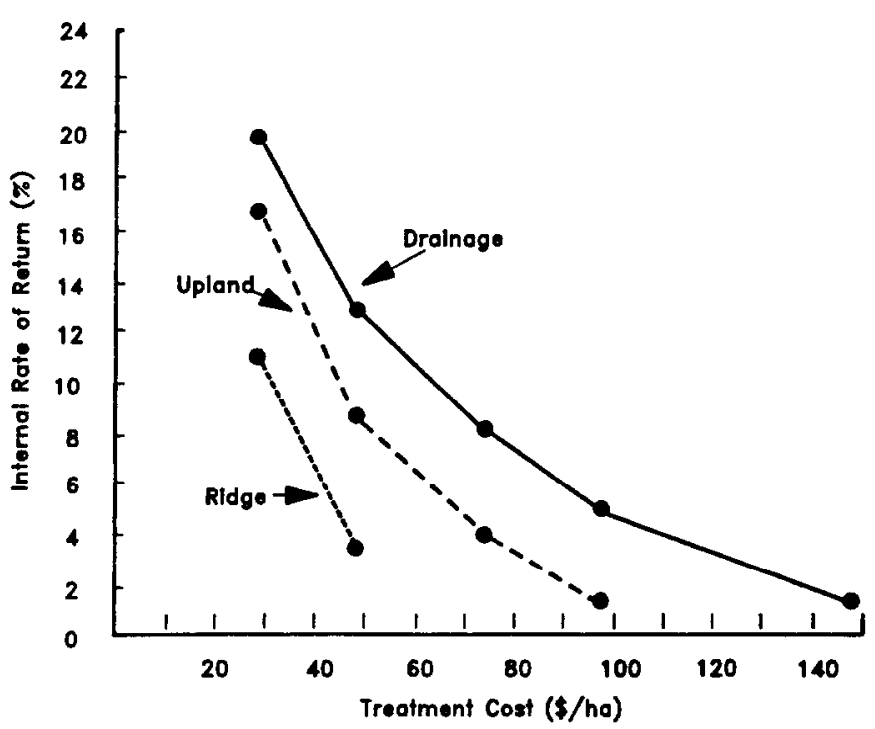

Fis. 2. Relationship between treatment cost and projected internal rates of return after application of tebuthiuron at $2.2 \mathrm{~kg} / \mathrm{ha}$ to sites of varying production potential within mixed-brush dominated landscapes near Pearsall, Texas.

projected, posttreatment livestock carrying capacities between locations. Honey mesquite was the most common highly tolerant species on both areas but the category included Lindheimer pricklypear (Opuntia lindheimeri), tasajillo (Opuntia leptocaulis), lime pricklyash (Zanthoxylum fagara), Texas persimmon and coyotillo (Karwinskia humboldtiana).

Potential productivity varied considerably among sites within locations. Projected IRRs were highest following application of $2.2 \mathrm{~kg} / \mathrm{ha}$ of tebuthiuron to the more mesic drainages having relatively deep soils than to upland sites or to the ridges (Fig. 2 and 3).

Based on treatment costs in the range $\$ 24.71$ to $\$ 144.50 /$ ha, IRRs were greater following application of tebuthiuron at 2.2 $\mathbf{k g} /$ ha to drainages near Pearsall (Fig. 2) than following treatment of a similar site near Laredo (Fig. 3). This response differential was attributed to the higher proportion of tebuthiuron-susceptible species, primarily whitebrush but including spiny hackberry and Berlandier wolfberry (Lycium berlandieri), in the drainages near Pearsall (Table 3). Mortality of whitebrush exceeded $90 \%$ by the second growing season following tebuthiuron application, regardless of location.

Investment required to generate a $10 \%$ IRR varied with relative forage production capability among sites. Whereas $\$ 62.80 /$ ha could be invested in treatment of drainages near Laredo with the exception of generating a $10 \%$ IR R, no more than $\$ 43.45 /$ ha could be invested in upland sites. Only about $\$ 27.70 /$ ha could be invested

Table 3. Relative cover of woody species by category of susceptibility to tebuthiuron pellets and absolute cover of mixed brush on 3 generalized sites with mixed-brush dominated areas where pattemed applications were evaluated near Pearsall and Laredo, Texas.

\begin{tabular}{|c|c|c|c|c|c|c|}
\hline \multirow[b]{3}{*}{ Susceptibility category } & \multicolumn{6}{|c|}{ Woody canopy cover (\%) by site } \\
\hline & \multicolumn{2}{|c|}{ Drainage } & \multicolumn{2}{|c|}{ Upland } & \multicolumn{2}{|c|}{ Ridge } \\
\hline & Pearsall & Laredo & Pearsall & Laredo & Pearsall & Laredo \\
\hline $\begin{array}{l}\text { Highly tolerant } \\
\text { Tolerant } \\
\text { Susceptible } \\
\text { Highly susceptible }\end{array}$ & $\begin{array}{r}1.0 \\
5.8 \\
25.7 \\
67.5\end{array}$ & \begin{tabular}{r|}
5.3 \\
33.4 \\
37.3 \\
24.0
\end{tabular} & $\begin{array}{r}1.9 \\
27.8 \\
65.4 \\
4.9\end{array}$ & \begin{tabular}{r|}
3.3 \\
34.3 \\
50.1 \\
12.3
\end{tabular} & $\begin{array}{l}0 \\
0.7 \\
89.0 \\
10.3\end{array}$ & $\begin{array}{c}2.4 \\
17.4 \\
80.2 \\
0\end{array}$ \\
\hline Absolute cover & 95.7 & 80.3 & 52.4 & 41.3 & 72.5 & 39.7 \\
\hline
\end{tabular}




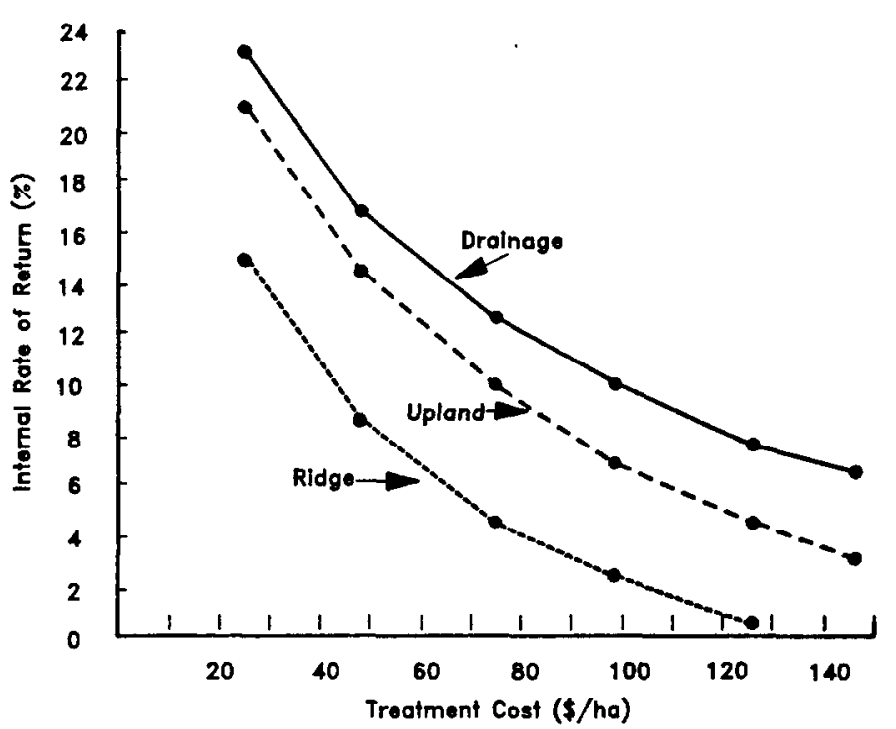

Fig. 3. Relationship between treatment cost and projected internal rates of return after application of tebuthiuron at $2.2 \mathrm{~kg} / \mathrm{ha}$ to sites of varying production potential within mixed-brush dominated landscapes near Laredo, Texas.

in treatment of ridge sites using a $10 \%$ IRR as the decision criterion. Maximum investments in treatment of sites near Pearsall with the expectation of generating a $10 \%$ IRR were $\$ 99.25 /$ ha for drainages, $\$ 74.70 /$ ha for upland sites, and $\$ 43.05 /$ ha for ridges.

The relative economic performance of tebuthiuron applied to various sites was substantiated by comparison of projected NPVs at the end of the hypothetical planning profile (Table 4). The NPV comparisons were calculated by changing only the cost of treatment. All other variables in the analyses remained constant. Regardless of location, magnitude of investment in treatment which produced a positive accumulated NPV were ordered, drainages $>$ uplands $>$ ridges. Within a site classification, a positive NPV was projected with less capital input for the area near Pearsall than near Laredo.

\section{Conclusions}

Results of this study indicate the potential for designing variable rate patterns which are economically competitive with application of herbicide in strips. Consideration of site potential when assign- ing dosages within the patterns can enhance economic performance. For example, strip patterns are largely site indiscriminant. Using the present study areas as examples, patterns which assign higher tebuthiuron rates to drainage sites and lower rates (or no herbicide) to shallow ridges would improve the annual rate of return on a pasture-wide basis. Although tebuthiuron served as the example in this study, the influence of site would likely be expressed regardless of herbicide used. Further, the interaction of botanical composition of the brush stand with site potential is requisite to optimum economic performance of herbicides. The greater cover of honey mesquite on sites near Laredo negated positive economic outcome from tebuthiuron application, compared to returns from the study location near Pearsall. The negative impact of herbicide-tolerant species on such sites often may be largely overcome by strategically programming followup, low cost treatments such as prescribed burning in the planning profile (Scifres 1987).

\section{Literature Cited}

Beasom, S.L., and C.J. Seifres. 1977. Population reactions of selected game species to aerial herbicide applications. J. Range Manage. 30:138-142.

Cottam, G., and J.T. Curtis. 1956. The use of distance measures in phytosociological sampling. Ecology 37:451-460.

Garolan, L., J.R. Conner, and C.J. Scifres. 1984. Economic evaluation of fire-based improvement systems for Macartney rose. J. Range Manage. 37:111-115.

Hopkin, J.A., P.J. Barry, and C.B. Baker. 1973. Fina ncial management in agriculture. Interstate Printers and Pub., Danville, Ill.

Seifres, C.J., and B.H. Koerth. 1986. Habitat alterations in mixed brush from variable rate herbicide patterns. J. Wildl. Soc. Bull. 14:345-356.

Scifres, C.J. 1987. Economic assessment of tebuthiuron-fire systems for brush management. Weed Tech. 1:22-28.

Seifres, C.J., J.L. Mutz, and W.T. Hamilton. 1979. Control of mixed brush with tebuthiuron. J. Range Manage. 32:155-158.

Tanner, G.W., J.M. Inglis, and L.H. Blankenship. 1978. Acute impact of herbicide strip treatment on mixed-brush white-tailed deer habitat on the northern Rio Grande Plain. J. Range Manage. 31:386-391.

Whitson, R.E., and C.J. Scifres. 1980. Economic comparison of alternatives for improving honey mesquite-infested rangeland. Texas Agr. Exp. Sta. Bull. 1307..

Whitson, R.E., and C.J. Scifres. 1981. Economic comparison of honey mesquite control methods with special reference to the Texas Rolling Plains. J. Range Manage. 34:412-415.

Whitson, R.E., S.L. Bessom, and C.J. Scifres. 1977. Economic evaluation of cattle and white-tailed deer response to aerial spraying of mixed brush. J. Range Manage. 30:214-217.

Whitson, R.E., W.T. Hamilton, and C.J. Scifres. 1979. Techniques and considerations for economic analysis of brush control alternatives. Texas A\&M Univ., Range Sci. Dep. Tech. Rep. 79-1.

Table 4. Net-present values (NPV) of treatment of range sites of varying forage production potential with tebuthiuron pellets at 2.2 ka/ha near Pearsall and Laredo, Texas.

\begin{tabular}{|c|c|c|c|c|c|c|}
\hline \multirow{3}{*}{$\begin{array}{l}\text { Treatment cost } \\
(\$ / \text { ha) }\end{array}$} & \multicolumn{4}{|c|}{ NPV (\$/ha) by site } & \\
\hline & \multicolumn{3}{|c|}{ Pearsall } & Laredo & & \\
\hline & Drainage & Upland & Ridge & Drainage & Upland & Ridge \\
\hline $\begin{array}{r}24.71 \\
49.42 \\
74.13 \\
98.84 \\
123.55 \\
144.50\end{array}$ & $\begin{array}{r}74.55 \\
49.84 \\
25.13 \\
0.42 \\
-24.29 \\
-45.33\end{array}$ & $\begin{array}{r}49.71 \\
25.00 \\
0.29 \\
-24.42 \\
-49.13 \\
-70.13\end{array}$ & $\begin{array}{c}18.34 \\
-6.37 \\
-31.08 \\
55.79 \\
-80.50 \\
-101.50\end{array}$ & $\begin{array}{r}38.10 \\
13.40 \\
-11.31 \\
-36.02 \\
-60.73 \\
-81.74\end{array}$ & $\begin{array}{r}18.74 \\
5.97 \\
-30.68 \\
-55.39 \\
-80.10 \\
-101.10\end{array}$ & $\begin{array}{r}3.00 \\
-21.71 \\
-46.42 \\
-71.13 \\
-95.84 \\
-116.84\end{array}$ \\
\hline
\end{tabular}

"Based on a $10 \%$ discount rate over a 20 -yr planning profile. 